Discourse and Communication for Sustainable Education, vol. 9, no. 1, pp. 86-99, 2018

\title{
Sustainability in the German School System: Inclusion of Minorities into the Teacher Education Workforce
}

\author{
Andreas Brunold \\ Augsburg University, Germany
}

\begin{abstract}
There is no doubt about the necessity for the inclusion and the integration of minority groups in German school system. Although there are different recognised politics and developments within the school policy of the 16 federal states in Germany, there are also common important political issues. While heterogeneity in minority groups is emphasised, the under-representation of minority groups in the education workforce can also be recognised. Of course, this can be seen not only as a matter of social justice, but also as a question of a responsible integration-policy by the (national) state, its political system, institutions, and culture. The present study outlines the problems and chances which are connected with the practical work of teachers with a migration background for the school service in Germany. In addition, examples of good practice in aspects of networks and mentoring, information and awareness-raising are indicated.
\end{abstract}

Keywords: civic and political education, German education system, integration-policy, naturalisation test, teachers with a migrant background.

\section{Situation of Migrant Teachers in the German School System}

In Germany, it is the duty of every teacher to accept the basic law, if she or he wants to work in a public school as an educator and/or a teacher. This is more obvious for teachers working as civic educators, transferring political knowledge, skills, and attitudes to the students to be and become good and cohesive democrats and citizens, in the sense of a "citoyen".

To practice as an official teacher in public schools in Germany, one must have German nationality. This requirement indeed limits the possibilities of work in schools and colleges for those who do not meet citizenship criteria. This is obviously a limiting factor even for those who have acquired the required qualifications to practice as teachers.

In view of the rising and overwhelming refugee crisis in Europe, especially in Germany, political education by and for the citizens is becoming more and more important. Institutions as well as schools in Germany are confronted with this question: how successful integration of the migrants can take place in the political community. Only in this way can migrants become new fellow citizens (GPJE, 2015). 
In public, a discussion is held mainly about linguistic competence and occupational measures as a basis for successful inclusion. However, not less important is the knowledge about the bases of democracy and the possibilities for its development. A successfully established integration requires therefore on the one hand, the acceptance of the basic values and central principles of a multipluralism and liberal democracy, on the other hand - the active co-operation of the citizens in a democratic and civil society - not only on the job market but also in the communities. Therefore, the basic political and social conditions of integration should be established.

Among the demographic trends in Europe and of course in Germany, two are particularly salient: population decline and population aging (United Nations, 2000). Focusing on these two striking and critical trends, it is really a question of whether replacement migration can be a solution to declining and aging populations, without endangering the democratic culture and identity of the European countries. Thus, if we look at the ecological footprint and the necessities of sustainable development, we might get to the position that a slowly shrinking population worldwide surely will be helpful for a sustainable global development (Brunold, 2015; Ohlmeier \& Brunold, 2015). From this point of view, the motivation of Civic Education Teachers-in-Training in the Field of Education for Sustainable Development is highly important (Hiller \& Reichhart, 2017). This was already committed by the international community within the UN Decade of Education for Sustainable Development (Ohlmeier, 2013).

The integration-policy of minority groups in the German society is a new challenge for political education. Hence, political education is a universal and central task in the school system, also for refugees and minority children in preparatory classes (GPJE, 2015). While German school children, due to political education as a separate subject in the German school curriculum, in their majority are already familiar with basal images of democracy, this is surely not true for many refugees and minority children. On the other hand, schools are the only institutions, which can guarantee an exhaustive mediation of suitable knowledge, skills, attitudes, values, and competencies for participation-processes, so that the chance should be seized to prepare the students for their lives as citizens.

Therefore, political education must be in the view of extremely different migration biographies, so that all school forms should emphasise civic education for migrants as an essential component of their own school curriculum. If one does not succeed in anchoring the value base and the rule of law into the institutions of the society permanently, the internal peace of the community is endangered (Brunold, 2010).

\section{The Beutelsbach Consensus}

However, political education for democracy is not the only matter at schools. Tying on to the courses offered, which prepare for the German-naturalisation test, other formats should also be developed for migrants and refugees, to promote their political competence.

Supporting successful integration by political education in the longer term requires a suitable accompanying research. A successful integration-policy should, therefore, be aware of the so-called "Beutelsbach Consensus", which was developed in 1976 by the "State Centre of political education Baden-Württemberg" (Germany) and has an outstanding and central importance in German political didactics (Brunold, 2017). The consensus consists of three rules (Landeszentrale für politische Bildung Baden-Württemberg, see https://www.lpb-bw.de/beutelsbacher-konsens.html): 


\section{Prohibition Against Overwhelming the Pupil}

It is not permissible to catch students unprepared or unaware - by whatever means for the sake of imparting desirable opinions and to hinder them from "forming an independent judgment". It is precisely at this point that the dividing line runs between political education and indoctrination. Indoctrination is incompatible with the role of the teacher in a democratic society and the universally accepted objective of making scholars capable of independent judgement.

\section{Treating Controversial Subjects as Controversial}

Matters which are controversial in intellectual and political affairs must also be taught as controversial in educational instruction. This demand is very closely linked with the first point above, for if differing points of view are lost sight of, options suppressed, and alternatives remain undiscussed, then the path to indoctrination is being trodden. We have to ask whether teachers have in fact a corrective role to play, that is, whether they should or should not specially set out such points of view and alternatives, which are foreign to the social and political origins of students (and other participants in programs of political education). In affirming this second basic principle, it becomes clear, why the personal standpoint of teachers, the intellectual and theoretical views they represent and their political opinions are relatively uninteresting. To repeat an example that has already been given: their understanding of democracy presents no problems, for opinions contrary to theirs are also being taken into account.

\section{Giving Weight to the Personal Interests of Pupils}

Pupils must be put in a position to analyse a political situation and to assess how their own personal interests are affected as well as to seek means and ways to influence the political situation they have identified according to their personal interests. Such an objective brings a strong emphasis on the acquisition of the necessary operational skills, which is, in turn, a logical consequence of the first two principles set out above. In this point of view, the reproach is sometimes made, that this is a "return to formalism" so that teachers do not have to correct the content of their own beliefs. This is not the case since what is involved here, is not a search for a maximum consensus, but the search for a minimal consensus.

\section{Barriers of and for Minorities in Germany}

With reference to integration-policy, it is obvious that educators have an important role to play in institutions and have responsibility for minorities who are quite underrepresented but are in need to be created as socially cohesive citizens (BAMF, 2012). This is true for the biggest minority in Germany, the Turkish migrants, a minority of nearly 4 million people. Here the institutional selection process for becoming a teacher is not easy, because many of these candidates do not fulfill the standard requisites and competences of this profession. One of the main barriers is, of course, the language competency as the medium of instruction. 
On the other hand, if we look at textbooks, also cultural expectations can be seen very clearly. Here it is a fact that most of the textbooks are following the curriculum, so that national standards are mostly important. In all of the 16 federal states in Germany, where all have their own education system, the curricula are written to be more or less multi-cultural instead of being mono-cultural. Therefore, the schools have the task to adapt heterogeneity as a value, and to include minorities in the classrooms. Meanwhile, the impact of minority communities, for example Turkish and Islamic associations, seems to cause problematic schooling because they often have their own "informal and hidden” curricula (Amelina \& Faist, 2008).

There are very few migrants, who have already worked as teachers/educators in their previous countries. Another problem seems to be the equivalence of their qualifications and cultural orientation, which goes along with negative stereotyping, feelings of racism and discrimination by the society and its representatives, even in schools and universities. Therefore, the integration-process is not just a problem of entry into the profession, but also of retention and support to the once employed teacher.

In Germany, out of my individual experience, there is no lack of political will to be seen, although it is evident, that teachers with a migrant background are under-represented in schools (Donlevy, Meierkord, \& Rajania, 2016).

According to PISA data, $13.1 \%$ of 15 -year old learners have the migrant background, of which the majority are second-generation migrants (10.5\%) (OECD, 2013b). The largest groups amongst those with migrant background are from Turkish origin (6.5\% of all children aged 0-15), Polish (2.4\%) or Russian (2.1\%) (Destatis, 2014). According to PISA data, only $1.6 \%$ of learners at the age of 15 belong to language minorities (OECD, 2013b). Limited data are available on the learner population belonging to the four recognised ethnic minorities in Germany - the Danish, Sorbs, Frisians and Sinti or Roma. Compared to the group of learners with the migrant background, these groups are small.

The limited data show that the diversity of teachers (as measured by those with the migrant background) lags behind that of the learners. Microcensus data from 2007 suggest that only $7.3 \%$ of staff at ISCED levels $0-1$ and $4.7 \%$ of staff at ISCED levels 2-3 have the migrant background (Autorengruppe Bildungsberichterstattung 2010). One of the contributing factors may be that fewer university students with the migrant background study to become teachers - only $6 \%$ study to become teachers compared with $12 \%$ of the general population of university students (Karakasoglu, 2010, p. 91). According to the Report of the Federal Commissioner for Migration, Refugees and Integration on the Situation of Foreigners in Germany (BAMF 2012), available empirical evidence suggests, that the key barriers to teacher diversity are the following:

\section{Lack of Qualifications Needed to Take Part in Initial Teacher Education}

Many pupils with the migrant background do not attend a school which would lead them towards the university entry qualification needed to enter initial teacher education. The German school statistics show that, while $52 \%$ of German pupils attend academic secondary schools (Gymnasium), only 26\% with non-German citizenship attended this type of school in 2010/2011 (BAMF, 2012). Moreover, PISA analysis for Germany has repeatedly shown that 15 -year olds with the migrant background display significantly lower basic skills in literacy and numeracy than their non-migrant peers 
(OECD, 2013b). This implies that the population of potential students in initial teacher education with emigrant background is relatively smaller.

\section{Lack of Financial Resources Needed to Take Part in Initial Teacher Education}

While there is no direct empirical evidence of this barrier available, it can be noted that people with a migrant background generally fare worse in Germany than those with a non-migrant background. According to a government report (Engels et al., 2011), nearly twice as many people with a migrant background were at risk of poverty $(26.2 \%)$, i.e. earning less than $60 \%$ of the median income, compared with those with a non-migrant background $(14.5 \%)$ in 2010 . The risk of poverty for first and second generation migrants differs only marginally. This implies that there may be significant financial barriers to taking up initial teacher education as, although capped student loans are available, there are opportunity costs which may lead students with the migrant background to take up more lucrative alternative options such as paid vocational education and training.

\section{Prejudices, Stereotypes, and Discrimination}

A number of regional studies have found some evidence that students in initial teacher education and the preparatory phase are confronted with prejudices, stereotypes, and discrimination related to their migration background. A study on the experience of 200 teachers with the migrant background conducted at the Humboldt University Berlin (Georgi, 2010) finds that, while the vast majority of teachers with the migrant background feel recognised by their colleagues in their role, they experience different forms of discrimination in their daily work to different degrees of intensity. This includes discrimination based on the ethnic-cultural background, language skills, religious discrimination, as well as structural and institutional discrimination. Many of the teachers surveyed have experienced discrimination in different phases of their education career: $29 \%$ state to have experienced discrimination or disadvantage while being at school themselves, $13 \%$ during initial teacher education, $23 \%$ during the preparatory practical training and $22.5 \%$ in their current work as teachers. A regional study on students in initial teacher education also find qualitative evidence of discrimination during practical training and show that any deficits of students with the migrant background in initial teacher education are often attributed to that background by career support staff (Wojciechowicz, 2013). However, it should be noted, that these experiences did not necessarily lead to teachers or teacher candidates to leave the profession.

The question is, what are typical barriers or differences in Germany and in matters of migration and integration policies? Let us have a short glance to the present "refugee crisis", which is inflicting Europe in a more or less destabilising way, that is by now indeed a very hindering factor to the deeper integration with the "Old Continent". By looking at the three pillars of the Maastricht treaty (Commission of the European Communities, 1992) it can be recognised, that it is not that the supranational pillar is weak or is indeed the problem, but the intergovernmental regime and cooperation has its deficits and lacks in the European community. It can be clearly seen, that the goal of the European Community, "Unity in Diversity" cannot be fulfilled unless the European member states acts in solidarity. This depends of course very much on the different 
political systems and the political cultures in the member states. This can clearly be recognized, looking at the negative effects of the so-called "refugee crisis" in Germany and the other member states of the European Union (Morillas, Sánchez-Montijano, \& Soler, 2015).

In many German classrooms, there are more students with foreign roots than "locals". Many kinds of influence from other cultures are increasingly making their marks on school life in Germany. Because of the rising number of learners with a migration background, there is surely an urgent need for more teachers with such a background (BAMF, 2015). So, a teacher with a migration background might be capable to:

- support the promotion of multilingualism in schools,

- help to make key improvements to cooperation with parents with the migration background to overcome the cultural gap,

- introduce multiculturalism to the staff-room by making an important contribution to the understanding of different cultures amongst colleagues,

- be an important role model for successful education careers for migrants above and beyond working as a teacher (BAMF, 2015).

But, before that, there are some barriers to manage. If a migrant is living in Germany permanently, he or she can become naturalized under certain circumstances. To do so, it is necessary to submit an application, once the applicant has turned to 16 years of age. Parents must make the application on behalf of children and young people under the age of 16 .

\section{The Naturalisation Test}

Since 1 September 2008, applicants for the German nationality have to demonstrate that they know about Germany's legal and social system and about what life is like in Germany (Federal Ministry of Justice and Consumer Protection, 2016). To this end, a standard nationwide naturalisation test was introduced at this time (AMF, 2008). Based on administration agreements, the Federal States, which are responsible for naturalisation, have commissioned the Federal Office for Migration and Refugees (BAMF) with the task of implementing the tests. The naturalisation test can be taken at over 560 test centres in Germany approved by the Federal Office. These are mainly adult education centres. Attendees must pay a flat fee of 25 Euros for the test. Everybody has a right to naturalisation, if the applicant fulfils the following conditions (Federal Ministry of the Interior/Federal Office for Migration and Refugees, 2014):

- have an unrestricted right of residence at the time of being naturalised,

- having passed the naturalisation test (knowledge of the legal and social system, as well as living conditions in Germany),

- the habitual, lawful place of residence has been in Germany for eight years (this period can be reduced to seven years if the individual attends an integration course successfully, and can be reduced to as few as six years in the case of special integration measures),

- have independent means of securing living without resorting to welfare payments and unemployment benefit,

- have adequate German-language skills,

- have no records on account of a criminal offence, 
- be committed to the free democratic constitutional order of the Basic Law of the Federal Republic of Germany, and

- decide to give up the former nationality (exceptions apply with regard to this point, depending on the country of origin).

By passing the naturalisation test, one can prove to have the knowledge of the legal and social system and living conditions in Germany, that is needed to be naturalised (Federal Ministry of Justice and Consumer Protection, 2016). The test can be done at the Federal Office for Migration and Refugees' test centres. In the examination, one will be given a test paper, containing 33 questions from different areas (BAMF, 2008). The time to answer the questions is 60 minutes. One must select the correct answer to each question from four possible answers. If the answer to the minimum of 17 questions is correct, one will pass the test. The successful participant will then receive a certificate with the test results from the Federal Office for Migration and Refugees (BAMF) and can then use this certificate to provide the proof of civic knowledge to the naturalisation authorities. If less than 17 questions are answered correctly, one can repeat the test.

Thirty questions relate to the subject areas of "Living in a democracy", "History and responsibility" and "People and society". Three questions will be asked about the Federal State, in which one is registered as having its main place of residence. An overview of all the important topics for the test is provided by the General catalogue of naturalisation test questions and the binding Curriculum framework for the naturalisation course (BAMF, 2008).

The applicant can prepare for the naturalisation test by using an interactive list of questions in the Federal Office for Migration and Refugees' online test centre. The test consists of a total of 310 multiple-choice questions, of which 300 are general questions that can be used throughout the Federal Republic and 10 specific questions related to each of the 16 Federal States, in which the applicant is living. Some Federal States also offer courses helping to prepare for the naturalisation test. If anyone has to prove adequate German-language skills for naturalisation, he or she can attend an integration course and obtain the "DTZ - German test for immigrants" certificate. Part of the integration course is a 60-lesson orientation course, that also tackles many topics, covered by the naturalisation test.

The naturalisation test is a pure test of knowledge. Linguistically, the test questions are set at level B1 of the Common European Reference Framework for Languages, so that candidates will not fail due to the lack of German-language skills. All the questions are based on the content of the curriculum for naturalisation courses developed by the BAMF. The Institute for Quality Development in Education at the Humboldt University in Berlin has developed this comprehensive questionnaire for the test (BAMF, 2008). There are 100 different test questionnaires available in each Federal State, which ensures, that no two candidates in any test group are given the same questionnaire.

The "Life in Germany" test takes place on a specific date after the orientation course has been finished. It includes questions about Germany's political system, its religious diversity and equal rights for men and women. The list of questions for the "Life in Germany" test and the orientation course curriculum provide an overview of all the important subjects covered by the test. 
The naturalisation test and preparatory courses are measures that can assist the integration in the German school and education system. Because the German naturalisation test consists of easily learnable knowledge and therefore is unrestrictedly reproducible, it is obvious that the test should be used only as one single measure among others for the integration of minorities. Moreover, an active discussion about the culture, history, society and the democratic political system by the migrants is necessary.

Anyone who does not have a basic knowledge of the legal system, society and the living conditions in Germany (Federal Ministry of Justice and Consumer Protection, 2016), has not necessarily internalised the civic democratic values as they must correspond to the "mind of the basic law". In spite of that, the role of a mature citizen, in general, requires a longer-term political socialisation process. Therefore, legal naturalisation must lead to the acceptance of the German political and democratic culture by the migrants and must be connected, in the end, with a commitment to the democratic constitutional system enshrined in the Basic Law of the Federal Republic of Germany. This commitment not only encloses knowledge of the German legal system and society, but, above all, also political judgment and action competences as well as democratic values and attitudes towards a "constitutional patriotism".

The social and political integration of migrants has not succeeded in Germany up to now. Actually, this can be recognised by the fact, that, on 16 April 2017 in Germany, approximately $14 \%$ of the Turkish migrants with a double citizenship voted for the amendments to the constitutional reform by the national referendum in Turkey (Council of Europe/European Commission for Democracy through Law, 2017). The approval for this constitutional reform in Turkey was $51.3 \%$ whereas in Germany, it was $63.1 \%$.

\section{Access and Employability of Migrants into Teacher Education Workforce in Bavaria (Germany)}

The language barriers and the political socialization processes surely have their influence on the access and employability of migrants into the teacher education workforce in Germany. To identify the barriers and obstacles in respect to this, it is clearly to be seen that, in contrary to other member states of the European Union, the financial limitations to enter German universities are moderate, because the fees are very low or generally do not exist anymore. Nevertheless, there is a wide range of models existing in the teacher education system in Germany, especially in Bavaria, in which we can find a lot of good-practice examples of teachers with the migrant background. These teachers are well integrated, had studied in higher education institutions, such as universities, and are now serving as good examples as role-models to be followed by their students. They mostly had got over difficult life relationships, because of the lack of family support and insufficient financial encouragement and aid. One of the most important programs in Bavaria is called "LeMi - Bayerisches Netzwerk der Lehrkräfte mit Migrationsgeschichte", which can be translated as "Bavarian network for teachers with a migration history background" (see http://www.lemi-netzwerk.de).

Because the Ministry of Education in Bavaria wants to have more migrants to become teachers, special courses and seminars are organised to give information about the professional duties of teachers in primary and secondary schools. The aim is to provide insight into the teaching studies and the chances of the teaching profession for scholars and students with a migration history. Special students' campuses are offering 
an overview of the varied duties and career chances for teachers. They receive information about the teaching studies and about the abilities as well as requirements for their career as a teacher. Moreover, they get to know what a good teacher might be and explore themselves whether they are suitable for the teaching profession. Therefore, they experience school not as students, but by work shadowing. The spectrum of professional experience discloses school classes and information about the everyday life of teachers.

The motivation to pursue a career as a teacher in Bavaria or in another federal state in Germany could also be related to a good and secure job and earning an adequate amount of money. As in some federal states in Germany, for example in Bavaria, a teacher could work in a position as a life-time civil servant, what brings indeed some advantages to the active teaching service, also concerning the pension, when he or she will be retired. Hence, there are not only barriers to be identified for migrants to find access to the employability of the German education workforce system but also examples of good practice in integration.

\section{Examples of Good Practice in Germany in Aspects of Networks and Mentoring, Information, and Awareness-Raising}

The German national action plan for integration from 2011 (Bundesregierung, 2011) sets out the national strategy for the integration of people with the migrant background in Germany across a range of policy areas. In the area of education, the strategy sets as one of its operational targets to increase the share of personnel with the migrant background in education and social work. It provides the general framework for actionin this area and links specific measures and instruments to indicators of success.

In Germany, some regional networks of teachers with the migration background exist. One of the most prominent is the "Projekt Lehrkräfte mit Zuwanderungsgeschichte in Nordrhein-Westfalen" which can be translated as the "Teaching staff with migration history in the North Rhine-Westphalia project” (BAMF/Gemeinnützige Hertie-Stiftung, 2011). It implements activities around three objectives:

1) attracting young people with migrant background to the profession,

2) accompanying them through their studies through networks, and

3) retaining and developing them within the profession.

Other mentoring approaches include the mentoring programme "MigraMentor" (MigraMentor-Campus, 2015), which ran first between 2011 and 2013 and provides mentoring for three different target groups:

1) potential students of initial teacher education,

2) actual students of initial teacher education, and

3) practising teachers, which ran between 2011 and 2014.

Giving financial support, there have been established a wide range of other projects designed to attract more migrant students to enter initial teacher education. The scholarship programme "Horizonte" supported by the Hertie-Foundation has offered scholarships and intellectual support to students with the migrant background in initial teacher education or vocational training in pre-primary childcare since 2008. The scholarships are supported through other foundations, universities and education ministries in the federal states (BAMF/Gemeinnützige Hertie-Stiftung, 2011). 
Several initiatives aim to raise awareness of the challenges faced by pupils with the migrant background. These often include initiatives targeted at students at upper secondary level. An example is the project "Schülercampus - mehr Migranten werden Lehrer" which can be translated as "Campus for pupils - more migrants are becoming teachers", which has been implemented since 2008 in a cooperation between the "ZEIT-Foundation" and the Federal Office for Migration and Refugees (BAMF). It includes targeted careers counselling for students at upper secondary level who are interested in a teaching career and who have the migration background. During multi-day workshops, they receive a basic introduction to pedagogy, learn about the opportunities and challenges of being a teacher and hear about first-hand experiences of becoming and working as a teacher from teachers with the migration background.

To make the teaching profession more attractive, there have been established other successful programs to integrate more migrants into the teacher education workforce. The pilot project "Praxisorientierte Erzieherausbildung - PiA", which can be translated as "Practically-oriented training for pre-school teachers", is implemented in the federal state of Baden-Württemberg (Ministerium für Kultus, Jugend und Sport Baden-Württemberg, 2015). PiA pays a training allowance for all three training years, and has a stronger practical component and targets applicants with completed vocational training or university entry qualifications. One of the proclaimed aims is to attract underrepresented groups to pre-school initial teacher education, including those with the migrant background.

Table 1

Overview of the Circumstances for Immigrants and Migrants to Find Access to Employability into the German Education Workforce System (Adopted from Brunold)

\begin{tabular}{|c|c|c|c|}
\hline $\begin{array}{c}\text { Aspects of time/ } \\
\text { phases of } \\
\text { qualification }\end{array}$ & New immigrants & $\begin{array}{l}\text { Second or third } \\
\text { generation } \\
\text { immigrants }\end{array}$ & $\begin{array}{c}\text { Established } \\
\text { minority } \\
\text { communities }\end{array}$ \\
\hline
\end{tabular}

Entry to teacher Recognition of qualifications education courses in universities

Achievement of entry qualifications are still weak and has their deficits

To become a teacher needs fluently language competences Often Turkish and Moslem people leave early secondary schools and have in the medium of instruction no sufficient language competences from the beginning on

To become a teacher needs fluently language competences in the medium of instruction from the beginning on

Bias in admission Cultural understanding processes
Often second or third generation immigrants still live in "parallel societies" and in their own communities

Education in general and civic/citizenship education is not a value for some minority groups
Measures are funded by governmental and non-governmental organisations (churches) for integration into the society. Still lack of role models/ cultural capital 
Sequel to Table 1.

There is no finance for courses There is no finance for additional in civic education in Germany, only for language courses courses in civic education in Germany, but mostly for language courses

Insufficient language

Insufficient language competences competences

Entrance and qualification

Entrance and qualification tests tests

Access restriction (numerus Access restriction (numerus clausus) clausus)

\begin{tabular}{lll}
\hline $\begin{array}{l}\text { Pre-service/ } \\
\text { beginner teacher } \\
\text { education }\end{array}$ & $\begin{array}{l}\text { They need to have the } \\
\text { German nationality, what } \\
\text { probably is not the case }\end{array}$ & $\begin{array}{l}\text { They need to have the German } \\
\text { nationality, what might often be the } \\
\text { case }\end{array}$ \\
\hline $\begin{array}{l}\text { They need excellent German } \\
\text { language competences, what } \\
\text { probably is not the case }\end{array}$ & $\begin{array}{l}\text { They need excellent German language } \\
\text { competences, what probably might be } \\
\text { the case }\end{array}$ \\
$\begin{array}{l}\text { The society might have stereo- } \\
\text { types and prejudice towards }\end{array}$ & $\begin{array}{l}\text { The society might still have stereotypes } \\
\text { and prejudice towards teachers with a } \\
\text { teachers with a migration } \\
\text { background, especially to } \\
\text { Muslims and people from the } \\
\text { near east }\end{array}$ & $\begin{array}{l}\text { those with the Muslim background and } \\
\text { people from the near east }\end{array}$ \\
& $\begin{array}{l}\text { Lack of Recognition of } \\
\text { teaching qualifications }\end{array}$ & $\begin{array}{l}\text { There could be still a lack of Recog- } \\
\text { nition of teaching qualifications }\end{array}$ \\
\hline $\begin{array}{l}\text { In Germany the state offers } \\
\text { the opportunities for bilingual } \\
\text { education in schools }\end{array}$ & $\begin{array}{l}\text { There is a lot of support to teachers } \\
\text { with the migrant background, especially } \\
\text { for continuing education measures }\end{array}$ \\
$\begin{array}{l}\text { There is no separation between } \\
\text { the state and the church in } \\
\text { Germany }\end{array}$ &
\end{tabular}

\section{Conclusions}

It is quite obvious, that even second or third generation immigrants in Germany still live in "parallel societies" and therefore often in their own communities. So there are measures and politics needed by governmental and non-governmental organisations to integrate these immigrants into society. While traditional countries of immigration like Australia, Canada, New Zealand and the United States of America have a longer tradition in immigration policy, for Germany, the debate over how to manage immigration is critical to its future. There are tendencies of adopting a point system similar to the one in Canada. There, Germany sees an immigration system that is open about its priorities, attracts a large pool of qualified applicants and, most importantly, enjoys widespread domestic support.

$$
* * *
$$

This article is dedicated to Prof. Peter Cunningham, Metropolitan University London. 


\section{References}

Amelina, A., \& Faist, T. (2008). Turkish migrant Associations in Germany. Between integration pressure and transnational linkages. Revue européenne des migrations internationals, 24(2), 91-120, Retrieved from http://www.universitaetbielefeld.de/ tdrc/ag_comcad/downloads/amelina_turkish_migrant.pdf

Autorengruppe Bildungsberichterstattung im Auftrag der KMK und des BMBF [Authoring group educational reporting by order of the KMK and the BMBF] (2010). Bildung in Deutschland 2010 [Education in Germany 2010]. Bielefeld: Bertelsmann Verlag.

BAMF (2008). Einbürgerungstest. Testfragebogen für das Bundesland Berlin. [Naturalisation Test. Test Questionnaire for the Federal state of Berlin], Retrieved from http://www.bamf.de/SharedDocs/Anlagen/DE/Downloads/Infothek/Integration/ Sonstiges/musterbogen_einbuergerungstest.pdf?_blob=publicationFile

BAMF/Gemeinnützige Hertie-Stiftung [non-profit Hertie-Foundation] (2011). Lehrkräfte mit Migrationshintergrund. Handlungsempfehlungen zum Netzwerkaufbau. [Teachers with migration background. Action recommendations to the network construction].

BAMF (2012). Bericht der Beauftragten der Bundesregierung für Migration, Flüchtlinge und Integration über die Lage der Ausländerinnen und Ausländer in Deutschland. [Report of the Federal Commissioner for migration, refugees and integration on the situation of foreigners in Germany], June, 2012.

BAMF (2015). Recruiting immigrants to the teaching profession. Retrieved from http://www.bamf.de/EN/Willkommen/Bildung/Studium/MigrantenLehrberuf/ migrantenlehrberuf-node.html

Brunold, A. (2010). Politisches Lernen zwischen Heterogenität und Bildungserfolg. [Political learning between heterogeneity and educational success], In Weißeno, G. (Ed.), Bürgerrolle heute. Migrationshintergrund und politisches Lernen. [Civil role today. Migration background and political learning], Schriftenreihe der Bundeszentrale für politische Bildung, [Publication series of the German Federal Agency for Political Education]. Band 1050, Bonn, 203-217.

Brunold, A. (2015). Civic education for sustainable development and its consequences for German civic education didactics and curricula of higher education. Discourse and Communication for Sustainable Education, 6, 30-49.

Brunold, A. (2017). Wie tragfähig ist der Beutelsbacher Konsens heute? Ein Statement. [How stable is the Beutelsbach consensus today? A statement], In Frech, S., \& Richter, D. (Eds.), Der Beutelsbacher Konsens. Bedeutung, Wirkung, Kontroversen. [The Beutelsbach Consensus. Relevance, impact, controversies], Didaktische Reihe Beutelsbacher Gespräche, [Didactic series Beutelsbach conversations]. Schwalbach/ Ts., 87-103.

Bundesregierung (2011). Nationaler Aktionsplan Integration. [National Action Plan for Integration]. Berlin, December, 2011.

Commission of the European Communities (1992). Treaty on European Union. Office for Official Publications of the European Communities, Luxembourg, 253. Retrieved from https://europa.eu/european-union/sites/europaeu/files/docs/body/treaty_on_ european_union_en.pdf

Council of Europe/European Commission for Democracy through Law (Venice Commission) (2017). CDL-AD (2017)005. Opinion No. 875/2017, Strasbourg, 30. Retrieved from http:/www.venice.coe.int/webforms/documents/default.aspx? pdffile $=$ cdl-ad (2017)005-e 
Destatis (2014). Bevölkerung und Erwerbstätigkeit [Population and employment], Statistisches Bundesamt Wiesbaden, 60.

Donlevy, V., Meierkord, A., \& Rajania, A. (2016). Study of the European Commission for Education and training on the diversity within the teaching profession with particular focus on migrant and/or minority background. Annexes to the Final Report to DG Education and Culture of the European Commission, Brussels: EU Publishing.

Engels, D., Köller, R., Koopmans, R., \& Höhne, J. (2011). Zweiter Integrationsindikatorenbericht. [Second German report on integration indicators]. Köln/Berlin, Beauftragte der Bundesregierung für Migration, Flüchtlinge und Integration.

Federal Ministry of the Interior/Federal Office for Migration and Refugees (BAMF) (2014). Welcome to Germany. Information for immigrants, 127. Retrieved from http://www.bamf.de/SharedDocs/Anlagen/EN/Publikationen/Broschueren/ willkommen-in-deutschland.pdf?_blob=publicationFile

Federal Ministry of Justice and Consumer Protection (2016). Nationality Act of the Federal Republic of Germany. Section 10/\$10, Retrieved from https://www.gesetzeim-internet.de/englisch_rustag/englisch_rustag.pdf

Georgi, V. (2010). Lehrende mit Migrationshintergrund in Deutschland: Eine empirische Untersuchung zu Bildungsbiographien, professionellem Selbstverständnis und schulischer Integration. [Teachers with migration background in Germany: An empirical study on education biographies, professional self-image and school Integration]. Retrieved from http:/www.fu-berlin.de/presse/informationen/fup/2010/fup_10_ 281/index.html

Gesellschaft für Politikdidaktik und außerschulische Jugend - und Erwachsenenbildung - GPJE [Society for political didactics and extracurricular youth education and adult education] (2015). Stellungnahme der GPJE zum Thema "Politische Bildung für Flüchtlinge”, Retrieved from http://gpje.de/wp-content/uploads/2017/ 01/Stellungnahme_pB_Integartion_2015.pdf

Hiller, K., \& Reichhart, B. (2017). Motivation of civic education teachers-in-training in the field of education for sustainable development. Discourse and Communication for Sustainable Education, 8(1), 81-89.

Karakasoglu, Y. (2010). Vortrag im Rahmen des Bundeskongresses Lehrkräfte mit Migrationshintergrund - Potenziale gewinnen, Ausbildung begleiten, Personalentwicklung gestalten. In: BAMF (ed.), Bundeskongress Lehrkräfte mit Migrationshintergrund, Kongressdokumentation. [Federal conference teachers with migrant background], 86-101.

Landeszentrale für politische Bildung Baden-Württemberg. [State Centre of political education Baden-Württemberg], Retrieved from https://www.lpb-bw.de/ beutelsbacher-konsens.html

LeMi - Bayerisches Netzwerk der Lehrkräfte mit Migrationsgeschichte. [Bavarian network for teachers with a migration history background], Newsletter, Retrieved from http:/www.lemi-netzwerk.de/_download/LeMi-Newsletter-Juni-2016.pdf

Ministerium für Kultus, Jugend und Sport Baden-Württemberg (2015). Informationspapier zur praxisintegrierten Erzieherinnen und Erzieherausbildung in BadenWürttemberg mit Fördermöglichkeit nach dem Sonderprogramm WeGeBAU der Arbeitsagentur (BiA-WeGeBAU, Retrieved from https://www.baden-wuerttemberg. de/fileadmin/redaktion/dateien/Remote/km/pia-wegebau_2016-03-09.pdf 
Morillas, P., Sánchez-Montijano, E., \& Soler, E. (2015). Europe and the refugee crisis. 10 side-effects. CIDOB Barcelona Centre for International Affairs. Colleción Monografías, 33

OECD (2013a). Excellence through equity, 2, Paris: OECD Publishing.

OECD (2013b). Results from PISA 2012, Country note Germany. Paris: OECD Publishing.

Ohlmeier, B. (2013). Civic education for sustainable development, Discourse and Communication for Sustainable Education, 4, 5-22.

Ohlmeier, B. \& Brunold, A. (2015). Politische Bildung für nachhaltige Entwicklung. Eine Evaluationsstudie. [Civic education for sustainable development. An evaluation study]. Wiesbaden: Springer Verlag.

Senatsverwaltung für Bildung, Jugend und Familie Berlin. [Berlin Senate Department for Education, Science and Research], MigraMentor-Campus 2015, Retrieved from http://www.zukunftscampus-berlin.de/kulturelle-vielfalt/migramentor/Infos_ Vorgaengerprojekt_MigraMentor.pdf

United Nations Population Division (2001). Replacement Migration: Is it a solution to declining and ageing populations? ST/ESA/SER.A/206. New York, Retrieved from http://www.un.org/esa/population/publications/migration/execsum.pdf

Wojeciechowicz, A. (2013). Kulturelle Differenz als positionszuweisendes Deutungsmuster von Akteurinnen und Akteuren in der Praktikumsbegleitung von Lehramtsstudierenden aus Einwanderungsfamilien. [Cultural difference as determining pattern of interpretation of actors in the supervision of practice elements of students with migration background in initial teacher education], In Bräu, K., Georgi, V., Karakaşoğlu, Y., \& Rotter, C. (Eds.), Lehrerinnen und Lehrer mit Migrationshintergrund - Zur Relevanz eines Merkmals in Theorie, Empirie und Praxis. [Teachers with migrant background - on the relevance of an attribute in theory, empiricism and practice], Münster, New York, München, Berlin: Waxmann.

Correspondence concerning this paper should be addressed to Andreas Brunold, Augsburg University, Germany. Email: andreas.brunold@phil.uni-augsburg.de 